\title{
Form and Substance in Law and Morality
}

\author{
Leo Katz†
}

\begin{abstract}
When lawyers do what lawyers do best are they being wicked?

Here are some familiar examples of what I have in mind. (1)
\end{abstract} A lawyer asks a witness a question ostensibly to impeach his credibility but really to bring out some embarrassing fact that might prejudice the jury. If the question is sufficiently "relevant" he will get away with it, not necessarily because the judge is asleep at the switch, but because the price of introducing probative evidence often is that sort of prejudice. (2) A lawyer instructs his client to shred some embarrassing memoranda before litigation arises in which they might become relevant. (3) A lawyer suggests to a client who owns a farm that she incorporate the farm and declare herself its employee in order to qualify for social security. (4) A lawyer devises a compensation package for a corporation that is replete with nontaxable fringe benefits, spacious offices, sumptuous meals, and lengthy vacations. (5) A lawyer recommends to elderly clients that they distribute their assets to their children so that they qualify for governmental assistance more quickly. (6) A lawyer recommends that a client turn most of its employees into independent contractors to escape the burden of social security taxes or even simple tort liability.

Is this sort of thing all right? There are basically two positions on this, No and Yes. The Nos would usually simply invalidate transactions like those above. But sometimes they will threaten to go even further-witness the recent attempt by Congress to make it a crime for professionals to advise clients on how to "dispose of assets (including by any transfer in trust) in order for the individual to become eligible for medical assistance under a State plan."1

The Yesses refer to such legislation as the "Granny's Advisor Goes to Jail Act." Their position is that once certain rules have

$\uparrow$ Professor of Law, University of Pennsylvania. I owe special thanks to Larry Alexander, Dan Farber, Richard Pildes, Mark Rosen, and Claire Finkelstein for their written and unwritten comments.

${ }^{1} 42$ USCA \& 1320a-7b(a)(6) (Supp 1998). A federal district court disallowed enforcement of the provision because it violated the First Amendment. New York State Bar Association v Reno, 999 F Supp 710, 716 (N D NY 1998). 
been adopted, it is the lawyer's prerogative to help clients aggressively exploit them. To be sure, the legislature can then amend the rules. But that's it. They can't invalidate actions that manage to take maximal advantage of them, and they certainly can't punish lawyers for explaining to clients how it can be done. The Yesses might even go so far as to applaud the Roman youth in days of yore whose story is reported by Seneca the Elder: having heard of a statute granting a stipend to victims of blindness, one young man arranged to have himself blinded! ${ }^{2}$

I addressed myself to this kind of problem at some length in a book called Ill-Gotten Gains. ${ }^{3}$ I joined the Yesses, but not for reasons having anything to do with the ones they familiarly give. The position I took elicited a considerable amount of criticism; the purpose of this Article is to defend, refine, expand, and qualify the thesis advanced therein. My answer to the problem-my thesis-was roughly this: Everyday morality is highly formalistic, in a sense not usually appreciated. Law tracks everyday morality, and is thus also formalistic in that same unappreciated sense. Lawyers who engage in the above kinds of shenanigans are simply capitalizing on the formality of the everyday morality that underlies law. And by the standards of that same everyday morality they are acting perfectly defensibly. The force of this thesis is perhaps best understood by emphasizing what it denies. It denies that law's formality is due to anything specifically legal, for example the need to draft rules that cannot avoid being somewhat over or underinclusive. It denies that lawyers are simply exploiting the legislators' lack of skill, foresight, or practical ability to draft non-over, non-underinclusive rules. It denies that the principle of legality that binds legislators to ill-drafted rules has anything to do with lawyers' ability to engage in shenanigans.

Those who have disagreed with me have done so principally on three grounds, and this Article is organized around those three grounds. First, they have insisted that no plausible morality, least of all anything deserving the name everyday morality, is formalistic in the sense in which I claim it is. Second, they have denied that law tracks that particular kind of weird morality. Third, they have argued that even by the lights of that weird everyday morality lawyers' shenanigans are morally indefensible. ${ }^{4}$

2 See John D. Ayer, How to Think About Bankruptcy Ethics, 60 Am Bankr L J 355, 373 (1986), citing Kitty Chisolm, ed, Rome: The Augustan Age 405 (Oxford 1981).

3 Leo Katz, Ml-Gotten Gains: Evasion, Blackmail, Fraud, and Kindred Puzzles of the Law 1-132 (Chicago 1996).

- See Larry Alexander, Is Morality Like the Tax Code?, 95 Mich L Rev 1839, 1847-49 (1997) (book review); Claire Finkelstein, Mens Rea and Other Criminal Inefficiencies, 8 


\section{ON THE FORMALISTIC CHARACTER OF EVERYDAY MORALITY}

There is a great and familiar divide in the way people organize their moral thinking. On the one side of that divide are the consequentialists, on the other the deontologists - the beancounters versus the priests, as Mark Gergen aptly named the two protagonists. ${ }^{5}$

The most familiar stripe of consequentialist is the utilitarian, who in turn comes in two varieties: rule utilitarian and act utilitarian. These are not the only kinds of consequentalists. What marks the consequentialist is that he believes that states of the world can be ranked and that the right course of action is the one that brings about the best state of the world. Utilitarians have a particular way of going about the business of ranking states of the world: they total up utility. Where rule and act utilitarians differ is in the strategy they recommend for attaining the utilitymaximizing state of the world. Rule utilitarians think it is best accomplished by sticking to certain well-chosen rules; act utilitarians think that each choice should be assessed with regard to its impact on overall utility.

Deontologists may or may not believe that states of the world can be ranked, but they certainly do not think that the right course of action is necessarily the one that brings about the best state. Other criteria are supposed to tell us what the best course of action is. The most prominent kind of deontologist is the libertarian, as 'best described in Robert Nozick's Anarchy, State, and Utopia. $^{6}$ For the libertarian deontologist, what determines whether an action is right or wrong is whether it violates certain "side constraints"-whether it transgresses the boundary that protects every person's individual rights. Whether we are dealing with such a transgression will hinge on whether someone has inflicted harm by an act or an omission, directly or indirectly, culpably or accidentally, and so forth. ${ }^{7}$

The difference between the consequentialist and the deontological approaches to morality emerges most saliently if one fo-

Crim L F 143, 152-59 (1997) (book review); Mark P. Gergen, A Priest Responds to the Bean Counters: Leo Katz on Evasion, Blackmail, Fraud, and Kindred Puzzles of the Law, 22 I \& Soc Inquiry 879, 885-88 (1997) (book review); Malcolm Gladwell, Loopholes for Living, New Yorker 88 (Apr 15, 1996) (book review); Richard A Posner, The Immoralist, New Republic 38, 39 (July 15 \& 22, 1996) (book review); Julie Turner, Ill-Gotten Gains: Evasion, Blackmail, Fraud, and Kindred Puzzles of the Law, 84 Cal L Rev 1492 (1996) (book review).

Gergen, 22 L \& Soc Inquiry at 879 (cited in note 4).

- Robert Nozick, Anarchy, State, and Utopia 33-35 (Basic Books 1974).

7 See id. 
cuses on so-called forbidden tradeoffs, the cases in which we could save several people by carving up one and confiscating his organs, or in which we could get a terrorist to reveal where he hid a bomb by torturing his child, or in which we could appease a menacing lynch mob threatening to torch a city by punishing an innocent prisoner. To be sure, both consequentialists and deontologists abhor such actions, but they do so for different reasons. Utilitarians do so because they think on various plausible empirical grounds that such actions would not really be utility-maximizing. Libertarians do so regardless of whether those empirical assumptions hold true. I should immediately qualify these statements. A utilitarian might in fact take the position that such actions should be avoided regardless of empirical assumptions, that it is categorically worse to kill one person than to let several others who could be saved by the use of his organs die. But he would be doing so on the ground that a state of affairs in which one person is killed by an act is worse than one in which several are simply permitted to die. Given this ground, he should be willing to allow a single instance of killing-one-for-the-sake-of-many if thereby he could avoid several more such instances. This really marks the most fundamental difference between the two positions.

\section{A. Formalism in Consequentialism Versus Formalism in Deontology}

Consequentialism, at least in some of its stripes, exhibits something that would seem to deserve the name formalism. Rule utilitarianism involves somewhat fetishistically sticking to a rule even though departing from it at that moment would in fact generate a better outcome. That certainly seems formalistic.

Deontological morality too is formalistic, but in a different sense. Because deontological morality makes certain tradeoffs impermissible, it necessarily incorporates into its picture of morality a crucial bit of what economists would call path dependence. Forbidden tradeoffs are situations in which an actor has the choice between two ways of precipitating certain adverse outcomes, and he is called upon to choose the more harmful one; he must choose that outcome despite the fact that it is more harmful, because of the path by which it is attained. He is required to "cause" the death of the five rather than the death of the one because that means he will be causing death by an omission rather than by an act. Deontologic morality, then, is formalistic because it involves sticking to a path even though departing from it at the moment would generate a better outcome. 
It is worth pausing to note the different ways in which rule utilitarianism and deontology are formalistic. Rule utilitarianism is formalistic in that it occasionally calls for people to do what is "substantively" the wrong thing-in the sense that it doesn't bring about the best state of the world-because it is "formally" the right thing; it conforms to a rule that will in the long run get us most often to the best state of the world. Deontology is formalistic in that it treats differently two actions that are "substantively" identical-in the sense that they are both aiming toward the same end result-depending on the form they take or the path they traverse to get to that end result. Rule utilitarianism is formalistic because it requires compliance with rules even when those rules prove over or underinclusive. Deontology is formalistic because of its emphasis on means as well as ends.

Larry Alexander has taken issue with my description of deontology as formalistic. He thinks I am distorting language when I call the act-omission distinction "formalistic." If the line between killing and letting die is morally significant, he argues, then it is substantive and not formalistic. ${ }^{8}$ Well, I would say, it is both substantive and formalistic. It is the hallmark of deontology that extremely formalistic aspects of our conduct become matters of substance. This may start to seem like a terminological quibble, but actually it is not. I take Alexander to say that when I call path dependence formalistic I am suggesting that it is formalistic in the same sense that the law is. And he doesn't think these two kinds of formalism have anything to do with each other. My grounds for thinking that they do will be the subject of a later section. For now, just grant me that deontology is formalistic in some not entirely arbitrary sense of the word. Later on, I will try to show that it is formalistic in precisely the sense most relevant to law.

But before doing so, I need to take up another issue. Many people find deontology utterly implausible, which is why they reject my thesis that the law's ubiquitous formalism is likely to be rooted in it. I won't try to establish the validity of deontology; I couldn't. But I think I can defend it against the charge of utter implausibility. Let's take a look at some of the most prominent criticisms.

\footnotetext{
- Alexander, 95 Mich L Rev at 1847 (cited in note 4); Larry Alexander, "With Me, It's All er Nuthin"': Formalism in Law and Morality, 66 U Chi L Rev 530, 559-60 (1999).
} 


\section{B. The Plausibility of Deontology}

1. Charges of irrationality.

(a) Path dependence. Some critics find it irrational that the same harm arrived at by one route should be judged differently if arrived at by another route. Interestingly enough, law and economics scholars and "crits" have found this feature of deontology equally objectionable. Mark Kelman took Richard Epstein (at that time still a deontologist) to task for drawing "distinctions like the following: it is tortious for a party to direct or shine light on another party's property in a fashion that diminishes the value of the property, but unexceptionable to block one party's access to valued light by building a tall building." In a similar vein, Richard Posner attributes the act-omission distinction to a premodern mindcast. To him the act-omission distinction "brings to mind the gravediggers' scene in Hamlet. One of the gravediggers argues jokingly ... that to be allowed to be buried in hallowed ground Ophelia must not have drowned herself but must instead have merely allowed the water to drown her."10

In response, the deontologist could of course proceed to make all sorts of moral arguments for the specific kinds of path dependencies that he is endorsing. He might ask people whether they really think that they should be considered the murderer of every person across the globe whose death they could have averted by a charitable donation. A better answer might point to the ubiquity of path dependence when making various other kinds of quasi-moral judgments. Indeed this is Robert Nozick's strategy when he discusses his famous experience machine, whereby we could provide ourselves with the simulacrum of a far happier life than we are actually likely to experience. Nozick's objective is to make path dependence plausible, to show that the same experience is far more valuable in real life than it would be if generated by an experience machine. ${ }^{11}$

Other notable path dependencies have to do with our life plans. We prefer not merely to have a life that maximizes utility, but one that involves an ascending rather than a descending path, even at the cost of some utility. This kind of path dependence too has a way of seeming irrational. Daniel Kahneman reports an experiment in which people willingly chose more pain

- Mark Kelman, A Guide to Critical Legal Studies 24 (Harvard 1987), referring to Richard Epstein, Nuisance Law: Corrective Justice and Its Utilitarian Constraints, $8 \mathrm{~J}$ Legal Stud 49, 60-65 (1979).

${ }^{10}$ Posner, The Immoralist, New Republic at 40 (cited in note 4).

$"$ Nozick, Anarchy at $42-45$ (cited in note 6). 
over less. ${ }^{12}$ Subjects in these experiments were required to go through two trials in which their hand was placed in painfully icy water. In the first trial, the hand was kept in for a few minutes, then immediately taken out. In the second trial, the hand was kept in the same amount of time, then for a few more minutes it was put into somewhat less icy but still painfully cold water, and then taken out. Subjects were asked which trial they prefer to repeat, and most said the second. ${ }^{13}$ Frances (F.M.) Kamm argues that, first appearances notwithstanding, there is really nothing irrational about the behavior of the subjects. ${ }^{14}$ All that the experiment shows, she says, is:

People prefer inclines . . . to declines ... . They would rather start as a clerk and move up to president than the reverse, even with utility held constant. This does not seem irrational to me. I believe that what Kahneman's results may suggest is that people apply this preference to what I call parsed events rather than to their life as a whole. For if a painful experience ends abruptly, this is a movement on an incline to a better state of affairs sooner and more steeply than if the pain is followed by diminishing pain before stopping. So overall, one's life is on a steeper incline if the pain stops abruptly earlier than if it stops later after petering out. But if the parsed event of, for example, a medical examination is conceived as ending when all pain ends, then that event ends on an incline (less bad, more good) only if the pain peters out rather than if it ends abruptly. The absence of pain is conceived as a new event or situation, and if it ceases abruptly, the previous event does not end on an incline. ${ }^{15}$

The same preference for inclines rather than declines probably plays a role in a very common but very odd attitude we have toward death. We are upset that we will no longer be alive fifty years from now, but not that we were not yet alive fifty years ago. For that matter, we do not think ourselves glad that we will no longer be around come World War III, but we do think ourselves glad that we were not yet around at the time of World War II. Moving from life to nonexistence is sadder than moving from

12 Daniel Kahneman, The Cognitive Psychology of Consequences and Moral Intuition 17-18 (Tanner Lecture on Human Values, University of Michigan 1994), discussing Daniel Kahneman, et al, When More Pain is Preferred to Less: Adding a Better End, 4 Psych Sci 401, 401-05 (Jan 1993).

${ }^{13}$ Id.

${ }^{14}$ F.M. Kamm, Moral Intuitions, Cognitive Psychology, and the Harming-versus-NotAiding Distinction, 108 Ethics 463, 485-86 (1998).

${ }^{15}$ Id at 485. 
nonexistence to life. ${ }^{16}$ Caring about the path we take to get somewhere is not unusual or irrational; we care about the path in all sorts of situations.

(b) Rejection of maximization. Other critics find it irrational that the deontologist-after concluding that organ harvesting is bad, that letting five die is better than killing one-should then not be willing to approve one instance of such a forbidden tradeoff to prevent many more instances of such forbidden tradeoffs in the future. ${ }^{17}$ In other words, they find it irrational that deontologists don't seek to maximize the number of outcomes that, by their own lights, are the most desirable.

Is deontology irrational for being nonmaximizing? Is libertarianism irrational because it does not allow the single breach of a side constraint if many more future breaches of side constraints could thus be averted? It would help to rebut this charge of irrationality if we could come up with other examples of nonmaximizing behavior that are not irrational, preferably examples that have a moral tinge to them. One example that I believe fits the bill is voting. Many voting systems on which we rely could be described as nonmaximizing. Many commonplace voting systems don't respect the Pareto principle; they might allow a collectivity to adopt a certain alternative even though everyone in fact would prefer another. That is most obviously true of voting systems like majority voting, which don't even allow us to achieve a consistent rank ordering of all the alternatives a society has to choose among. ${ }^{18}$ These systems, like deontological morality, only allow us to choose which of several alternative courses of action being considered right now should or should not be selected. They do not allow us to compare a list of final outcomes and choose the best one among them, or even to avoid choosing a Pareto inferior alternative from among them. ${ }^{19}$

In times past, it might have been thought a mark of irrationality for a society to allow its decisions to be controlled by such a voting system, but no longer. One lesson commonly drawn from

16 See generally F.M. Kamm, I Morality, Mortality: Death and Whom to Save from It 13-71 (Oxford 1993) (describing and attempting to account for our attitudes towards death and nonexistence).

${ }^{17}$ See generally Samuel Scheffler, The Rejection of Consequentalism 80-114, esp 82 (Clarendon 1994) (describing the "apparent air of irrationality" surrounding the idea of a forbidden tradeoff); Nozick, Anarchy at 28-33 (cited in note 6) (discussing moral side constraints).

${ }^{18}$ See William H. Riker, Liberalism Against Populism: A Confrontation Between the Theory of Democracy and the Theory of Social Choice 16-18 (W.H. Freeman 1982).

see id. 
Arrow's famous theorem ${ }^{20}$ is that the most basic demands we might place on a rational voting system cannot be fulfilled simultaneously. Only a subset of them can be satisfied by any given system, and that subset need not necessarily contain either the Pareto principle or even transitivity. A Pareto-violative, indeed even an intransitive voting system, has as much of a claim to representing the will of the collectivity as one that abides by Pareto optimality and by transitivity, but that fails to meet some other equally plausible desiderata. The nonmaximizing structure of libertarianism, or deontology generally, thus makes it no more irrational than many widely accepted voting systems.

(c) Reliance on intuition. Other critics find the deontologist's reliance on intuitions to be willful to the point of irrationality, akin to a mathematician refusing to accept a proof despite the fact that line-by-line he cannot quarrel with the argument, on the ground that it does not feel "intuitively" right.

This criticism makes me think of a line by the philosopher F.H. Bradley that "the man who is ready to prove that metaphysics is impossible is a brother metaphysician with a rival theory of his. own." The consequentialist has intuitions of his own, which he opposes to those of the deontologist. His most fundamental intuition is that we should be able to rank states of the world according to their moral desirability and that the most moral thing to do is to aim for the highest attainable one on the list. The deontologist's most fundamental intuition is that there are forbidden tradeoffs and that if ascending from one state of the world to another, arguably better one, involves such a forbidden tradeoff, then it is off limits. Both are intuitions, both can be fortified by other intuitions that cohere with them. Both have counterintuitive implications as well-counterintuitive, that is, from the point of view of the rival theory. But intuitions all the same.

I will, however, concede that there is something different about the types of intuition on which the two camps rely. The deontologists' intuitions are closer to the ground-he relies on his sense that certain kinds of tradeoffs just won't do. The consequentialist's intuitions have more of a "meta" flavor to them: a belief that a sensible system of morality should have certain structural properties, such as the property of allowing us to rankorder states of the world in terms of their moral desirability. De-

\footnotetext{
${ }^{20}$ Kenneth J. Arrow, Social Choice and Individual Values (John Wiley and Sons 2d ed 1963) (discussing the difficulties in aggregating individual choice into a stable collective preference).

${ }^{21}$ Alfred Jules Ayer, Language, Truth and Logic 34 (Dover 1952), quoting F.H. Bradley, Appearance and Reality: A Metaphysical Essay 1 (Oxford 9th ed 1930, repr 1955).
} 
ontological morality is basically our everyday morality: it is rooted in the intuitions we have about particular cases. Consequentialist morality by contrast offers itself up as an improvement on that crude, unenlightened, superstition-ridden everyday morality.

\section{The framing objection.}

An entirely different ground on which deontology is sometimes taken to task is the so-called framing problem. Critics argue that many of the classical deontological categories and distinctions are essentially meaningless, infinitely pliable, thoroughly indeterminate. Whether we consider something a case of killing or letting die is just a matter of how the event in question is framed. There is an abundance of illustrations to drive home the point. A child is trying to escape a ferocious dog; a malicious neighbor slams the door into the escaping child's face. Is this a case of killing or letting die? The only passenger in a runaway trolley fails to divert it onto another track to avoid running someone over. Do we have a killing or letting die? A would-be rescuer retrieves the life-vest he has just thrown to the drowning victim. Killing or letting die? These cases seem impossible to classify. They can be looked at either way, depending on how the facts are "framed." Utilitarians, economists, and "crits" alike take this to be proof of the vacuity of deontological ideas.

Mark Kelman has argued this point particularly aggressively in his Guide to Critical Legal Studies. ${ }^{22}$ He notes that a common way in which libertarians like to distinguish acts from omissions is to conduct a little thought experiment: Would the defendant's victim be better off if the defendant didn't exist? In the case of an act, the answer seems to be yes, in the case of an omission no. Commenting on this thought experiment, he argues that it is "uncontrollably manipulable."

$\mathrm{Y}$ calls $\mathrm{Dr} . \mathrm{X}$ in the middle of the night for emergency care and $X$ refuses. The world may seem to be no worse for $Y$ if we wipe out $\mathrm{X}$, and hence, according to this view, $\mathrm{X}$ has no duty (and there is thus no duress if $X$ charges a staggering sum to reverse his initial decision). If, though, one extends the thought experiment over time, one realizes that had $\mathrm{X}$ not

\footnotetext{
${ }^{22}$ Kelman, A Guide to Critical Legal Studies at 24 (cited in note 9).

23 Id.
} 
held himself out as a doctor in that town, another one might well have come along. ${ }^{24}$

Kelman thinks such indeterminacy afflicts all deontological ideas: causation, intention, coercion, fraud, attempt, complicity, recklessness. Not a one of them, he argues, is any less susceptible to reframing than the act-omission distinction.

There are two replies. The first is that these criticisms vastly underestimate our power to settle issues of seemingly irresolvable indeterminacy. Recharacterization questions constantly arise in the law, and they are resolved without caprice. A splendid case study of how this happens in tax can be found in Saul Levmore's article Recharacterizations and the Nature of Theory in Corporate Tax Law. ${ }^{25}$ In tax, a transaction is susceptible to a seemingly endless number of "reframings," yet we feel capable of settling on one characterization, which, upon reflection, seems head and shoulders above the rest. Subtle and unappreciated considerations of symmetry and consistency do the job. Levmore offers the example of a corporation with two shareholders, each owning 50 percent of the shares, one of whom is its chief executive, the other of whom is a passive investor. One year the corporation pays out some extra compensation to the chief executive, more than the market ordinarily pays for those kinds of services. The IRS refuses to view the excess as salary. Well, if it isn't salary, what is it? Numerous possible characterizations suggest themselves. For starters, we could view the excess as a dividend paid to that shareholder; or we could view it as a gift from the corporation; or we could view it as a gift by the other shareholder, preceded by a dividend paid to both of them; or we could view it as a redemption. Some of these seemingly acceptable characterizations quickly fall by the wayside. If we adopted the last suggestion and treated the excess salary as a redemption of some of the chief executive's shares, it would conflict with subsequent corporate law treatment of the two parties, which takes them as having equal voting rights. If we viewed it as a gift, we would have to assess a gift tax against the passive investor, which he might be unwilling to bear. If we viewed it as a dividend, we would be violating a corporate law rule that requires an equal dividend to all shareholders of the same class. ${ }^{26}$

\footnotetext{
24 Id.

${ }^{25}$ Saul Levmore, Recharacterizations and the Nature of Theory in Corporate Tax Law, $136 \mathrm{U} \mathrm{Pa}$ L Rev 1019 (1988).

${ }^{28}$ See id at 1022-32.
} 
There is something else to be said in reply to the indeterminacy claim. The claim is here, as it is so often, self-undermining. Human thought about human behavior necessarily uses the concepts that are supposed to be incorrigibly indeterminate. One cannot think about human behavior, whether in a utilitarian, deontological, or even descriptive, nonmoral way without relying on ideas of causation, intention, coercion, fraud, complicity, recklessness, act or omission (though not necessarily using those labels). One cannot even criticize the use of such concepts without employing such concepts. To allege that "framing" problems totally compromise those notions is to lapse into incoherence.

\section{The contractarian argument.}

One further criticism of the deontological approach proceeds along contractarian lines. It argues that no group of people would ever rationally continue to abide by a morality that exhibited such path dependence. They would contract out of it.

Those who make this argument concede that there often will be practical considerations that would lead people to avoid contracting out of the path-dependent rules of our everyday morality. There are, after all, all kinds of practical reasons supporting the act-omission distinction. ${ }^{27}$ But the deontologist says that the actomission distinction and related path-dependent rules are valid regardless of such practical considerations. In such a world, argues the critic of deontology, rational people surely would contract out of these silly rules. They would contract into a set of rules that maximized their welfare, in other words, utilitarian kinds of rules. But then, the critics say, what ethical force can the deontologist's path-dependent rules have when we are confident that under the very circumstances that constitute the test case for deontological ideas-namely circumstances in which there are no practical considerations supporting the rule-they would cease to hold sway because people would contract out of them ${ }^{28}$

The proper reply is that if people tried to contract out of deontology's rules they couldn't. If a group of citizens got together and tried to abolish the act-omission distinction or some other ridiculous looking path-dependent deontological rule, such a contract would not be valid-not valid, that is, by the lights of a de-

\footnotetext{
${ }^{27}$ See Posner, The Immoralist, New Republic at 40 (cited in note 4) (offering a compact list of some of them: "amateur rescuers often make things worse; punishing for not rescuing would make people steer clear of situations in which they might be in a position to rescue someone; it is hard to identify cases in which the rescuer would not have been imperiling himself").

${ }^{28}$ See Shelly Kagan, The Limits of Morality ch I (Clarendon 1989).
} 
ontological system of morality. How can I say such a thing? The very idea seems outrageous. Libertarians are deontologists par excellence, and it would seem that they would not have a problem with such a contract. If a group of citizens tried to get together and abolish the act-omission distinction as far as interactions between them were concerned, what could be wrong with that? From a libertarian point of view such a contract might seem totally unobjectionable, provided of course that the parties are competent, no one commits fraud or duress, and there are no impermissible third-party effects. However, many of the core beliefs that libertarians hold, in their capacity as deontologists, make it nearly impossible for them to stick to that familiar line. One simply cannot be a libertarian and approve of the freedom of contract as wholeheartedly as libertarians usually claim to. This is a large claim. I have argued it at length elsewhere..$^{29}$ It is not quite as outrageous as it sounds: it has strong affinities with Amartya Sen's well-known, if controversial, theorem about the Impossibility of a Paretian Liberal. ${ }^{30}$ If I am right, however, it takes the wind out of the contractarian objection to deontology. ${ }^{31}$

\footnotetext{
${ }^{29}$ Leo Katz, Responsibility and Consent: The Libertarian's Problems With Freedom of Contract, 16 Soc Phil \& Pol 94 (forthcoming 1999).

${ }^{\text {so }}$ Amartya Sen, The Impossibility of a Paretian Liberal, $78 \mathrm{~J}$ Pol Econ 152 (1970) (arguing that the principle of liberalism of allowing individuals to make their own choices is inconsistent with a Pareto superior solution).

${ }^{31}$ See Katz, 16 Soc Phil \& Pol 94 (cited in note 29). This claim is slightly less unprecedented than it would appear at first. Over the last few years a literature has started to emerge that supports this same point. The most important piece is Sen, $78 \mathrm{~J}$ Pol Econ at 152-57 (cited in note 30). Inasmuch as voluntary bargains, struck in the absence of force and fraud and third-party effects are Pareto-optimal, Sen suggested that certain ideas we have about rights don't square with the freedom of contract. The source of the tension he identified was a little different from the sources I identify in the above-cited essay. On the other hand, he wasn't claiming the source he identified to be the only possible one. Sen's claim has generated much discussion. In Nozick's recent book, The Nature of Rationality, he remarks in passing that "Sen's work on the Paretian liberal paradox shows that a very natural interpretation of the scope of individual rights and liberties, and of how the choices of society should be rationally organized, cannot be easily fit together. These notions need a new structuring." Robert Nozick, The Nature of Rationality xv (Princeton 1993). A famous piece by Allan Gibbard, A Pareto-Consistent Libertarian Claim, $7 \mathrm{~J}$ Econ Theory 388 (1974), is in the same spirit as Sen's paradox. Frances Kamm argues along somewhat related lines in her recent book. F.M. Kamm, 2 Morality, Mortality: Rights, Duties, and Status ch 11 (Oxford 1996). Finally, John Broome, in Weighing Goods: Equality, Uncertainty and Time 152-54 (Basil Blackwell 1991), and Isaac Levi, Pareto Unanimity and Consensus, $87 \mathrm{~J}$ Phil 481 (1990), have argued for the unacceptability of the Pareto principle in bargains involving uncertainty when both parties to a bargain differ radically in their assessment of pertinent probabilities.
} 
4. Deontology and folk physics.

All of this is not meant to convince you that the deontological point of view is the right one. I am arguing only that it is not absurd and that it is a fair picture of a large chunk of our everyday morality. It isn't even strictly necessary that you agree that deontology is plausible for you to accept most of my thesis about formalism in law-that law's apparently absurd formalism mirrors the perfectly sensible formalism of our everyday morality, and that lawyers who exploit that formalism are acting morally by the lights of that everyday morality.

If you absolutely can't stomach deontology, you could think of it the way many psychologists have come to think about the beliefs people hold about physics or statistics: utterly wrong, but wrong in interesting and systematic ways. There is a whole branch of psychology that seeks to map out the rhyme and reason behind people's fallacious beliefs about the way the physical world operates, beliefs that squarely contradict physics but that do exhibit a logic of their own. For instance, when you ask subjects what a rolling ball will do when it reaches a cliff, they routinely predict that it will just drop rather than descend in a parabola. And when you ask them what path a bullet will take if it is ejected from a spiral-shaped pipeline, they predict that it will continue to circle in ever-looser spirals, whereas it will in fact move in a straight line. These are not just simple mistakes, it turns out, but correspond to an entire world view, which psychologists have dubbed "folk physics," and which corresponds remarkably closely to actual pre-Galilean physics. If you wish, you could think of deontology in the same light, a moral world view descriptive of a silly but nevertheless coherent system to which those who fly by the seat of their everyday intuitions (like me!) have fallen prey. My claim about law, then, simply translates into the argument that it is this unenlightened "folk morality" that injects formalism into law and allows lawyers to exploit it. ${ }^{32}$

\section{FORMALISM IN LAW}

The law tracks our deontological everyday morality to a remarkable extent. Thus the formalism of that everyday morality is imported into the law.

\footnotetext{
I2 See generally Dedre Gentner and Albert L. Stevens, eds, Mental Models (Lawrence Erlbaum Assoc 1983); Daniel Kahneman, Paul Slovic, and Amos Tversky, eds, Judgment under uncertainty: Heuristics and biases (Cambridge 1982).
} 


\section{A. Criminal Law}

This is probably least controversial with respect to the criminal law. Criminal law forbids exactly those tradeoffs that everyday deontological morality forbids: no carving up of one for the sake of the many. It tolerates those tradeoffs that everyday morality tolerates: diverting the trolley from the track with the many to the track with the one. It differentiates between acts and omissions as painstakingly and seemingly as absurdly as everyday morality. The parallelism between the two becomes especially conspicuous when moral distinctions are turned up by moral philosophers of which the law has not yet taken cognizance, but which we can be certain are going to be incorporated. Some years ago two philosophers, Christopher Boorse and Roy Sorensen, drew attention to a category of cases in which it is inconceivable that an actor would be held criminally liable despite an apparently indisputable violation of the criminal law. ${ }^{33}$ They were cases in which someone intentionally and proximately caused death and whose acts quite clearly met the technical definition of murder; but morally the person was quite clearly guilty of no such thing. Boorse and Sorensen's example goes as follows: Victim is standing in a movie queue as an assassin is taking aim at him. Defendant, who is Victim's friend, rescues Victim by dragging him out of the path of the bullet. As a result, another person-the person standing behind the intended victim-is hit instead. There is little doubt that this would not be judged a murder, despite that fact that the defendant has knowingly and proximately caused the death of another human being. (Defendant would not have a necessity defense either, since he caused the death of one to save one.) Elsewhere I have offered a range of other examples all of which would technically qualify as murder, and all of which would seem to call for new defense categories. ${ }^{34}$ So close is the connection between criminal law and morality that whether the legislature ever actually bothers to codify these defenses or not, we can be confident that they will be provided. ${ }^{35}$

Another way in which the close connection between criminal law and everyday morality becomes apparent is the extent of allowable punishment-the proportionality constraint. Criminal law, as a first approximation (subject to qualifications that I will address in a moment), inflicts nonoptimal punishments, punish-

\footnotetext{
* Christopher Boorse and Roy A. Sorensen, Ducking Harm, 85 J Phil 115 (1988).

${ }^{3}$ Leo Katz, Proximate Cause in Michael Moore's Act and Crime, $142 \mathrm{U} \mathrm{Pa} L$ Rev 1513, 1519,1523 (1994).

35 Id at $1524-28$.
} 
ments that are commensurate with the wickedness of the deed, not punishments that create the appropriate degree of deterrence. Criminal law is by and large retributivist. Sometimes that means that it punishes more lightly than a utilitarian point of view would require. I suspect, for instance, that from a utilitarian point of view it would be desirable to inflict something like a life sentence for drunk driving. Sometimes the criminal law punishes more harshly than utilitarians would demand, as with criminals whose terrible deeds are for one or another reason certain not to inspire emulation even if they go unpunished..$^{36}$

There may seem to be some obvious counterexamples. There are, for instance, all those silly crimes that fill various curiosity collections. As Richard Posner points out, a "search through the federal criminal code reveals many absurdities, such as the criminalizing of the sale of merchandise stamped with the legend, 'Give a Hoot, Don't Pollute,' without the permission of the Department of Agriculture. ${ }^{37}$ But note how unstable these counterexamples are. They strike us as cruel and unusual. They rarely last. Prosecutors often don't enforce them; juries often nullify them; judges often denounce them. The same goes for other counterexamples to the claimed identity of criminal law and everyday morality: strict liability statutes and the current sentencing guidelines. Because they don't square with our deontological everyday morality, they seem cruel and unusual and, I suspect, won't last. The counterexamples do, however, certainly show that the criminal law is subject to a perennial temptation to slip the fetters of everyday morality and heed the utilitarian impulse.

The most formidable objection to the thesis about the equivalence of everyday morality and criminal law lies in the existence of a lot of seemingly immoral behavior that the criminal law declines to punish: like the failure of the "bad samaritan" to rescue someone in dire peril when he easily could have. There are actually many more examples like that; but for now I will offer just one more, though admittedly one that is far more artificial than that of the bad samaritan:

Septimus is a surgeon who has been curious about what it would be like to operate on someone while he, Septimus, is in a slight state of intoxication. Realizing that to do so would be criminally reckless, he never actually goes through with the experiment. Instead, he makes painfully sure to be quite free

\footnotetext{
${ }^{3}$ See Michael S. Moore, Law and Psychiatry: Rethinking the Relationship 240-42 (Cambridge 1984).

${ }^{n}$ Posner, The Immoralist, New Republic at 40 (cited in note 4).
} 
of alcohol when he is actually on duty. But when he is off duty, he maintains a constant state of slight intoxication. His reason for doing so is somewhat devious. He hopes that some day an emergency will arise in which he is the only person with surgical skills far and wide, and despite his intoxication, his help will be eagerly sought. This does indeed happen. In the course of operating, Septimus's hands shake quite violently and the patient suffers a good deal of damage which he would not have had Septimus been sober. ${ }^{38}$

What makes these cases such a challenge to the deontological view of the criminal law is that the law's failure to punish does not seem like a mere lapse or an unstable aberration in the way strict liability offenses or "Give a Hoot, Don't Pollute"-type laws are. There seem to be deeper reasons for the law's failure to punish. Yet if the law doesn't punish in these cases where everyday morality clearly and strongly disapproves of the defendant's conduct, how can it be said to track everyday morality? To my mind, this question poses the toughest challenge to retributivism to date. I don't have a complete answer, but I have some sense of what the answer ought to look like. It seems that there are different kinds of wrongdoing in everyday morality, and that only some of those merit punishment. In a certain sense, the nonrescuer behaves far worse than the purse-snatcher. But it seems clear that only the purse-snatcher truly merits punishment. What he has done registers on the scale relevant to the criminal law. We are free to engage in some kinds of wrongdoing because deep "libertarian" rights permit us to do so regardless of the harm we inflict. I may know that, by reading a certain unwholesome-seeming book and letting you know that I am reading it, I will do more damage to your mental and physical health than I would do if I stole your wallet. If I read the book solely to inflict distress on you, my actions are in a sense far worse than if I stole your wallet. Yet it also seems I don't merit punishment. On the scale of wrongdoing that everyday morality thinks relevant to the criminal law, I have not done anything blameworthy.

\section{B. Other Areas of Law}

Even those who grant that criminal law in substantial part tracks everyday deontological morality are loath to admit that this might be true of the rest of law. Criminal law is thought by many to be sui generis. Utilitarianism might fail here, but in

\footnotetext{
${ }^{3} \mathrm{Katz}, 142 \mathrm{U} \mathrm{Pa}$ L Rev at 1521-22 (cited in note 34).
} 
more practical, less openly "moralistic" areas of law it runs the show. I won't deny the remarkable explanatory power of the economic approach throughout much of law, but it is worth hunting for the anomalies, the phenomena with which utilitarianism has some trouble. Often as not, they turn out to be pockets of "deontology." Once those pockets have been located, many doctrines that at first glance seemed most comfortably explained along utilitarian lines start to warrant a second look as well. Let me draw your attention to a few of those pockets of deontology-in corporate law, torts, and tax.

\section{Corporate law.}

Basic Inc $v$ Levinson ${ }^{39}$ presents one such pocket of deontology. The Basic corporation repeatedly denied rumors that it was engaged in merger talks with another company-up until the moment that it announced it was about to enter into such a merger. The reason for the company's deception was straightforward and innocent: diplomacy requires secrecy. Telling the world you are engaged in merger talks might kill the deal. The problem was that there were stockholders who had sold shares right after the company had issued its deceptive denials. Those shares would have commanded a much higher price had it been known that a merger was on the horizon. The affected shareholders claimed to have been defrauded out of that price differential.

The shareholders, however, faced an interesting doctrinal hurdle, which propelled this case all the way to the Supreme Court. Most of the shareholders did not actually know about the company's false statements. Under the common law, a successful fraud claim requires the plaintiff to prove that he relied on the defendant's misrepresentation. ${ }^{40}$ The plaintiffs' lack of knowledge should have been the end of their case. It wasn't the end, how-

\footnotetext{
30 485 US 224 (1988).

40 The basic elements of a misrepresentation cause of action include:

1. A false misrepresentation made by the defendant ....

2. Knowledge or belief on the part of the defendant that the representation is falseor, ... that he has not a sufficient basis of information to make it ....

3. An intention to induce the plaintiff to act or to refrain from action in reliance upon the misrepresentation.

4. Justifiable reliance upon the representation on the part of the plaintiff, in taking action or refraining from it.
}

5. Damage to the plaintiff, resulting from such reliance.

W. Page Keeton, et al, Prosser and Keeton on the Law of Torts 728 (West 5 th ed 1984). 
ever, because the Basic plaintiffs did not bring their fraud claim under the common law; they made a federal fraud claim based on Section 10b-5 of the Securities Exchange Act. ${ }^{41}$ It was thus open to the courts to dispense with the reliance requirement if they thought the common law concept of fraud too burdensome for the plaintiffs to prove.

The Supreme Court decided to dispense with it. The Court reasoned that the purpose of the reliance requirement was to make sure that the defendant's lie has in fact caused a loss to the plaintiff. In the typical case, they reasoned, a lie does its damage because the victim hears it and acts on it. In the buying and selling of securities, however, a lie can do damage through its effect on the market price of the stock. ${ }^{42}$ The plaintiff shareholders were hurt by the company's lies despite the fact that they never actually heard or relied on those lies. So why shouldn't they recover?

What the Supreme Court here failed to appreciate is the deontological character of the concept of fraud. Specifically, the Court overlooked the deontological character of the common law's reliance requirement. The Court thought that the essence of fraud was the defendant's uttering a lie that causes harm to the victim. It did not realize that the precise way in which the defendant's lie causes such harm matters greatly. Fraud is a highly path-dependent form of misconduct. To see this, consider a hypothetical. Suppose a fraudulent art dealer sells a customer a painting that he vouches is an authentic $R$. The customer is thrilled and pays substantially more for the painting than he would have had he realized that it was a fake R. He hangs the painting up in his living room. Some time later a friend of his walks into that living room, sees the $R$, and falls in love with it. The friend knows nothing about art and has never heard of $\mathrm{R}$. $\mathrm{He}$ just wants to buy this painting. He asks to be quoted a price. The current owner decides to quote him the price he paid for it, plus ten percent. That sounds all right to the friend and that is what he pays. After a while, however, he falls out of love with the painting and wants to sell it. He turns it over to an auction house and now it quickly comes out that it is only a fake, worth a fraction of what he paid for it. Question: should the current owner be able to recover from the art dealer for his loss? There is no doubt that the original art dealer caused the current owner's loss, that he would never have paid as much for the painting as he did had

415 USC $\S 78 \mathrm{j}$ (1994).

${ }^{42}$ Basic, 485 US at 243-47. 
he not been deceived as a result of what the art dealer told his original customer. Under the Supreme Court's approach in Basic, the art dealer would be held liable. Under the common law approach, however, he would not be-because the element of reliance is absent. In this setting the common law approach sounds intuitively right. The reliance requirement is not merely a way in which causation is established. It is an essential part of the path by which a lie needs to do its harm before it qualifies as a fraud. I see no good moral reason to treat lies about mergers differently from lies about paintings.

2. Torts.

There is an odd feature about the way tort law evaluates negligence. When assessing whether a driver has behaved with the requisite care, we look at how he drove-whether he drove too fast, looked in the mirror often enough, kept enough of a distance to the car ahead-but we don't assess the wisdom of his decision to drive in the first place. In more technical parlance, we look at the tortfeasor's care level, not his activity level. The economist Steven Shavell asks why courts are disinclined to include activity levels in determining negligence. ${ }^{43}$ Shavell's answer has to do with the inaccessible nature of the information one would need to make such a determination.

To formulate a standard for the level of activity, courts would need to determine the character of the benefits parties derive from their activities. (Courts would have to inquire into the pleasure obtained from walking a dog or the need for and importance of driving somewhere.) Because these benefits often seem practically unknowable, attempts by courts to determine appropriate levels of activity would probably quickly land them in the most speculative of realms. Deciding on appropriate levels of care, although by no means an easy task, usually appears to be less problematic. (We can say with fair confidence that a dog that snaps at others should be leashed or that a person should not drive at 60 miles per hour along a residential street.) ${ }^{44}$

But the activity/care level distinction appears in areas devoid of such practical concerns. In fact, the distinction has been the subject of one of the most long-running debates in all of criminal law. The debate tends to center on cases in which a defendant

\footnotetext{
43 Steven Shavell, Economic Analysis of Accident Law 25-26 (Harvard 1987).

"Id at 25.
} 
takes extremely antecedent measures to precipitate harm. ${ }^{45}$ The example I gave earlier of a surgeon who keeps himself slightly drunk during his off hours hoping to get to operate on a patient while drunk is but one of a large family of such cases. (I discuss a few more of them in the next Section.) What all such cases have in common is that the defendant is behaving unobjectionably at the moment at which he is inflicting harm, but caused himself to be in a position to inflict such harm by some vaguely objectionable decision earlier on. At least in the hypothetical versions of these cases, we have all the information we may want to form a judgment about the defendant's behavior. Yet in most (but not all) such cases we are nonetheless disinclined to blame him enough to punish him. That suggests that the activity/care level distinction has a deontological rather than a practical (that is, utilitarian) basis.

3. Tax.

Deep at the heart of tax law are numerous path-dependent deontological norms, which tax scholars have been reluctant to acknowledge. The simplest surfaces in the income tax treatment of fringe benefits. Certain fringe benefits we tax, others we don't. The usual explanation is that practical difficulties stand in the way of valuing those benefits. My hunch, however, is that something else is involved, something that goes to the very nature of an income tax. The income tax does not aim to tax utility pure and simple. It seems not merely impractical but unethical to impose a higher tax on the congenitally happy person than on the congenitally depressed one. Income is a means for generating happiness. Fringe benefits are another means. It is inherent in our unwillingness to tax happiness pure and simple that we treat differently the person who achieves happiness directly and the

${ }^{45}$ A survey of the most significant scholarly, statutory, and case law treatments of this problem can be found in Michael Hettinger, Die "actio libera in causa," Strafbarkeit wegen Begehungstat trotz Schuldunfähigkeit?: eine historisch-dogmatische Untersuchung (Duncker \& Humblot 1988). For two of the most important scholarly treatments of the topic, see Joachim Hruschka, Strafrecht nach logisch-analytischer Methode: systematisch entwickelte Fälle mit Lösungen zum Allgemeinen Teil (de Gruyter 1983); Ulfrid Neumann, Zurechnung und "Vorverschulden": Vorstudien zu einem dialogischen Modell strafrechtlicher Zurechnung (Duncker \& Humblot 1985). In English, probably the most recent explorations of the topic are Paul H. Robinson, Causing the Conditions of One's Own Defense: A Study in the Limits of Theory in Criminal Law Doctrine, 71 Va L Rev 1 (1985) (describing legal treatment of actors who create the circumstances of their own defense and proposing separate liability on the basis of the actor's earlier conduct); Katz, Ill-Gotten Gains at 1132 (cited in note 3); and Leo Katz, Playing By, With, Around, Under, and Above the Rules: An Essay For and About Fred Schauer, in Linda Meyer, ed, Festshcrift for Fred Schauer (Hart forthcoming 1999). 
person who needs to earn income to generate happiness. When we are reluctant to tax fringe benefits we are really accommodating people who are able to generate happiness by means other than wealth.

The tax law here mirrors a deontological norm that is deeply woven into the psychology of envy. We tax what we are capable of envying. This is not a coincidence, since according to many the tax law is meant to push in the direction of greater equality-and reduce envy. And as it happens, we do not really envy people their happiness, we only envy them the means by which they aim to achieve such happiness. While I have no trouble recalling the intense way in which I have envied someone his brains, good looks, great wealth, or worldly success, I don't recall ever envying someone his happiness. It is the path dependence inherent in that fact, rather than anything practical, that accounts for the tax law's reluctance to tax fringe benefits.

\section{THE RUTHLESS EXPLOITATION OF FORM}

Path dependence is, as we have seen, a feature of our deontological everyday morality. It becomes a feature of law inasmuch as law mirrors that morality, and my claim has been that a lot of law, not just criminal law, mirrors that morality. But what happens when lawyers try to exploit that path dependence? What happens when they try to take advantage of the fact that, although attaining a certain goal by path 1 is immoral and illegal, getting there by way of path 2 is not? Stated this abstractly, it is hard to see how such a course of action should be objectionable. And yet many people find it objectionable when they encounter some of its concrete manifestations. Why do they balk when someone does the sorts of things I described at the outset: ask a witness a question ostensibly to impeach his credibility, but really to bring out some embarrassing fact that might prejudice the jury; shred embarrassing memoranda before they become the subject of litigation; distribute assets to one's children in order to qualify for governmental assistance; turn employees into independent contractors to escape tort liability.

\section{A. Punishment and Blameworthiness}

The problem of what if anything is wrong with such conduct takes its purest form in the criminal law. And if I am right about the roots of legal formalism, the answer to the problem in criminal law is the answer to the problem elsewhere. In the criminal law context, the problem reduces to issues like the following: 
What are we to do with the would-be murderer who drinks himself into a suitably deranged state, hoping to use that derangement as an excuse for his homicide? What are we to do with the would-be murderer who contrives to provoke his victim into making an ineffectual attack on him, whereupon he shoots him in self-defense? What, more generally, are we to do with the person who manufactures the circumstances giving rise to his excuse or justification?

It is tempting to think that there is a very simple way of handling these kinds of cases. Many have tried to dispose of them in the following way: It is true, they say, that on the face of it we should be reluctant to punish such evil-doers because we don't want to punish those who killed while insane or while trying to defend their life. But the first defendant really caused his victim's death when he got himself drunk, thereby inaugurating a causal process that resulted in his victim's death, and he wasn't deranged at that point. So punishing him presents no problem. Analogously, when the second defendant provoked his victim into attacking him, he then and there caused the victim's deathagain by inaugurating a causal process that resulted in his victim's death-and he did so at a time when he was not yet acting in self-defense. So there is no problem in punishing him either. In a way, this qualifies as the standard solution, certainly the one that has been most popular with criminal law scholars in various legal regimes. ${ }^{46}$

Unfortunately, it won't work. Or rather, sticking to it has the most unfortunate results. Having discussed many of those elsewhere, I will just draw your attention to the most compelling and easiest to grasp. In my two examples, let's make the defendant's strategic actions more antecedent to the crime than they already are. In the case of the self-drugging murderer, let's assume that he swallows the drug years ahead of the crime with the conditional hope that if he ever does commit a crime he will be able to invoke his diminished mental capacity as an excuse. Now it becomes very hard to consider swallowing the drugs as the beginning of the murder. In the case of the self-defense provocateur, let's assume that what he did was to join the police force in the hope that sometime during his career a criminal would be foolish enough to try to kill him and he would then get to kill in self-

\footnotetext{
45 See, for example, Michael S. Moore, Act and Crime: The Philosophy of Action and its Implications for Criminal Law (Clarendon 1993); Robinson, $71 \mathrm{Va} L \mathrm{Rev}$ at 30-31 (cited in note 45) (arguing that it is appropriate to punish actors with a legitimate defense if they culpably created the circumstances of their defense).
} 
defense. Again, it is hard to see how actions this removed could ever be treated as the beginning of the homicide.

The kind of stratagems used by my two would-be murderers can be used on a much vaster scale than these examples might suggest. The stratagems need not be confined to manufacturing special excuses or justifications, like insanity or self-defense. It is possible with regard to all the elements of a crime to plan ahead and arrange for the crime to exhibit fewer of the requisites of culpability than it otherwise would. One can try to make sure that a crime that needs to be committed by an act instead is committed by an omission; that a crime that requires a proximately caused result instead is caused nonproximately; that a crime that needs to be committed intentionally is instead committed recklessly; or that a crime that needs to be committed negligently is instead committed accidentally. Here are some examples:

1. Acts and omissions. In seeking to convince his readers of the moral irrelevance of acts and omissions, Glanville Williams actually offers a very simple example of how to turn an act into an omission. ${ }^{47}$ Just replace the respirator currently supporting a terminally sick patient with one that needs to be restarted every twenty-four hours. I am sure this very trick has been used to cope with existing euthanasia law, ${ }^{48}$ which makes failures to resuscitate acceptable under circumstances where active killings would not be.

2. Proximate causation. Again, euthanasia is probably the simplest example. Voluntary actions by intervening actors break the chain of causation. Thus if I want to commit a mercy killing, a good way to protect myself from liability is to insist that the victim commit the very last act required to activate the machinery of death, such as pulling the lever that causes the carbon monoxide to be released into his mask.

3. Mental states: Turning intention into recklessness. Consider the case of a man who takes out life insurance on his wife. Having done so, he sets fire to his house. He figures there is a fifty-fifty chance his wife will manage to escape the blaze. His hope of course is that she won't. If she dies, he will be guilty of an intentional homicide-murder.

Suppose, however, that after contemplating the above plan, it occurs to him that he can attain his objective-killing his wife and obtaining money in exchange-by a slightly different, legally safer route. Rather than taking out life insurance on his

"Glanville Williams, Euthanasia, 41 Medico-Legal J 14, 21 (1973).

ts See id at 18-19. 
wife, he takes out property insurance on some valuable paintings that happen to hang in his wife's bedroom. Then he sets fire to the house. He fully expects the flames to destroy the paintings and he thinks there is a fifty-fifty chance that his wife also will die in the blaze. Her death, however, is no longer his aim, it's just a byproduct of his scheme. What would he be guilty of if she does die? Not murder, because he did not intend for her to die, but most likely manslaughter: he will be found to have killed her recklessly.

Note what he has done: by the simple strategem of replacing the life insurance on his wife with "painting insurance," and proceeding in every other way as he did before, he has managed to transmute what would otherwise be an intentional killing into a reckless one. ${ }^{49}$

\section{B. Exploiting the Difference between Liability and Blameworthiness}

What is one to make of such maneuvers? In Ill-Gotten Gains, I took a rather blunt line: they are all OK ${ }^{50}$ When a defendant modifies his conduct and finds a moral path to a seemingly forbidden result, he has rendered his conduct morally (and legally) unobjectionable. When the murderer finds a way of committing his homicide that falls within the self-defense justification or the insanity excuse, then he is rightly off the hook. Although I think my position was basically sound, I have since been led to modify it in some ways. More importantly I think I have found ways to explain away the discomfort people feel about agreeing with that position.

I continue to think that, sometimes at least, such maneuvers are totally and unobjectionably OK. I offer two highly artificial examples in which it seems impossible to deny that contriving to choose path 1 rather than path 2 successfully improves the moral position of the strategizer. First, imagine the proverbial trolley heading down an incline and coming to the fateful intersection at which the passenger has the choice of either directing the trolley onto the track where it will kill one or letting it run over the five on his track. Imagine the passenger lets the trolley take its

19 The key to his strategy is to recognize the analytical difference between an uncertain result that is intentionally caused and an uncertain result that is recklessly caused: the intended result is a hoped-for end or the means toward a hoped-for end; the unintended result is a mere byproduct of something hoped-for. Frequently, as in this case, it is possible to transmute a risk that is a means to a hoped-for end into a byproduct of that hoped-for end.

${ }^{\text {so }}$ Katz, Ill-Gotten Gains (cited in note 3). 
course and run over the five, but does not kill them; the trolley only injures them in so peculiar a fashion that they could all be saved from death provided they receive certain critical transplants, to wit two lung transplants, two kidney transplants, and one heart transplant-just the set of organs that the man on the other track, the one who was spared, happens to possess. If the passenger now decides to kill that man in order to harvest his organs it would be murder. On the other hand, if he had simply run over that man to save the five, that would have been a permissible way of carrying out the tradeoff between the one and the five. Assuming we believe that these two ways of carrying out the tradeoff deserve morally different treatment, the planning aspect that is injected if someone considers the implications of carrying out the tradeoff in one way or another would not seem to make a moral difference.

Another artificial example that I believe is equally compelling exploits the assassination example I briefly discussed earlier. Imagine again the situation of an assassin taking aim at a victim who happens to be standing in a movie queue. Imagine the victim's friend who sees all of this happening and wants to save his friend. He considers two options: first, he could drag the person who is standing in front of the intended victim into the path of the bullet; second, he could simply drag his friend, the intended victim, out of the way. In either case the same third-party bystander would be killed. If someone therefore "strategically" chooses to save the intended victim's life by dragging his friend out of the way rather than by dragging the bystander into the bullet's path, it is hard to see how this "planning" aspect renders his actions morally objectionable.

The only question really is whether all cases of strategically exploiting path dependence are like this. I used to think they were. I now am no longer sure. The above-mentioned euthanasia examples $^{51}$ certainly seem to fit this mold. The person who chooses to conduct his mercy killing by using an "omission" machine, or the person who does so by having his victim pull the lever that activates the machinery of death, would seem to have rendered a previously impermissible act permissible by changing the path along which the goal is attained. But some cases of lawyerly strategizing may be different. Here are three that arguably fit into a slightly different category; they are cases in which someone morally deserves to get the benefit of strategic behavior which, unlike the above cases, seems quite immoral:

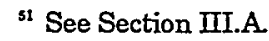


A third-world visitor to the United States, who would like to immigrate, makes a public statement that he knows will cause him to be persecuted back home. His only reason for making the statement is to qualify for political asylum in the U.S. ${ }^{52}$

A debtor approaching bankruptcy engages in "exemption planning." He pours all of his remaining assets into so-called exempt categories that even in the event of bankruptcy creditors may not seize: his house, clothing, certain kinds of pensions-in short, assets that the law regards as somehow on a par with the shirt on one's back. ${ }^{53}$

A protester, who wants to delay the military's installation of certain missiles, lies down in front of the tanks that are supposed to deliver the missiles. The tanks are stuck; they cannot run him over..$^{54}$

In all of these cases, someone engages in a strategic maneuver that makes use of certain deontological precepts: the precept that forbids us from throwing a persecuted man to the wolves, or from ripping a man's shirt off his back to pay his debts, or from killing someone if he does not actually threaten someone's life. The person so acting, however, is not really using a permitted rather than a forbidden path toward a certain end. There is no doubt that the protester lying down in front of the tanks is acting immorally and illegally. Nonetheless, he seems deserving of the strategic benefit he is seeking. The immorality and illegality of his conduct do not make it proper for the tank to run him over. He has gotten a moral benefit, but he still has behaved immorally. In that sense, he seems quite different from the strategizing passenger in the runaway trolley or the strategizing friend standing in the vicinity of the movie queue.

It seems possible that we should regard the conversion of assets in anticipation of an impending bankruptcy in the same light. Arguably, we find it impossible to rip the shirt off the bankrupt's back for the same reason we find it impossible to run the protester over with our tanks. But that doesn't mean the debtor behaved rightly. Wrongful behavior can sometimes successfully exploit a certain path-dependent feature in our morality. The path-dependent feature in question here is the fact that creditors can only collect their debts by certain means. Quite possibly, the would-be political refugee has put us in the same posioion as the protester or the bankrupt. If we do not grant him asylum we are

${ }^{52}$ See Katz, Ill-Gotten Gains at 6 (cited in note 3).

${ }^{53}$ See id at 7-8.

st See Leo Katz, Blackmail and Other Forms of Arm-Twisting, 141 U Pa L Rev 1567, 1571-73 (1993). 
in effect running him over. Or rather, we are handing him over to someone who will run him over, his home country's authorities. But our refusal to run him over does not entail blessing his conduct.

There is a second category of cases in which arguably someone should get the benefit of his moral strategizing without actually earning our full approval for his actions. As I mentioned earlier, sometimes it is possible for us to inflict a harm on someone by skillfully but maliciously exploiting our liberties. It might be possible for me to inflict great physical and mental distress on you by simply sufficiently upsetting you about something I am entitled to do, say, by telling you that I am reading something disturbing, or that I painted my bedroom purple, or that I enjoy killing and eating animals. It seems the essence of liberty that there are a few things that I can do quite without regard to how upsetting you find them. Thus, if I can succeed in rearranging some harm that I was about to inflict on you so that it is inflicted through my exploitation of some liberty that I have, then I have somehow gotten the moral benefit of my strategy. But I am still eligible for condemnation, just not the kind of condemnation that is required for criminal punishment. To me someone who deceives another without actually lying is eligible for condemnation, just not the kind of condemnation required for punishment. It strikes me that some of my opening examples may fall into this category: maybe the document shredder, or the lawyer who impeaches a victim to get into evidence some forbidden fact.

There is a final category, the one I regard as the most important and interesting. It is the one into which to my mind most cases of strategizing fall. Considering it will, I think, truly get to the bottom of how we can give someone the benefit of his strategic devices while also thinking that he did something wrong. There is a much overlooked, highly counterintuitive feature of our deontological everyday morality, which I intend to explore in great detail elsewhere but which I will for now only briefly sketch out.

Let's reconsider the classic instance of a forbidden tradeoff, the case of the utilitarian surgeon, but let's change the facts slightly. The ordinary case simply involves a surgeon who harvests the organs of his innocent victim and uses them to save five others. Let us now embellish the example in such a way that great heroic actions on the part of the surgeon are required to successfully implement his rescue operations. I won't provide details. I will just ask you to stipulate to that, or else supply your own details. If this is so, does that render his decision to harvest organs morally acceptable? I should think not. I find it hard to 
see how the heroic nature of his rescue efforts makes his ripping out the organs any more permissible. Consider now, however, a second question: how does this organ-harvesting, heroic surgeon compare with a hypothetical second surgeon who decides to do the right thing and not harvest organs, and who therefore does not get the opportunity for any heroic rescue operations? My claim is that the first surgeon might well be morally superior, despite the fact that he chose to do the wrong thing. How can that be? Well, consider the case of someone who committed a murder and subsequently tried to redeem himself by saving five people in the most heroic fashion imaginable. I take it that if he acted heroically enough, we would consider him morally superior to the surgeon who has committed neither a murder nor a heroic feat. But the surgeon who kills one in order to use his organs in an extremely valiant rescue operation of five others is surely no worse than the man who committed a murder and followed that up with an independent heroic rescue operation of five. So in the end we are entitled to conclude that the surgeon who killed the one for the sake of the many ended up in a morally superior position than the one who did neither.

This is bound to seem highly paradoxical. How can a deontologist say on the one hand that it is forbidden to sacrifice one person for the sake of saving several, yet say on the other hand that if someone carries out such a forbidden sacrifice he ends up in a morally superior position? This just seems absurd. The key to the paradox is to recognize that to the deontologist the process of making a decision and the process of evaluating a decision are quite distinct. When a deontologist chooses between two alternatives-letting the many die and the one live VERSUS heroically saving the many but killing the one in order to do so-he will not allow himself to just count up the good and the bad aspects of each alternative and then pick the alternative with the highest score. He will not allow the "good aspect" of many lives heroically saved to offset the "bad aspect" of one life extinguished. That would be a consequentalist calculation-just the kind deontologists refuse to engage in. Nevertheless, when a deontologist evaluates a person who has embarked on a certain course of action, even a forbidden course of action like killing one person in order to be able to save many more heroically, he cannot help taking into account both the good and bad aspects of that course of action. When a deontologist has to decide how harshly to punish someone who has done both good and bad things, he needs to assess the person's blameworthiness. In order to assess someone's blameworthiness, the deontologist needs to take into account both 
the good and the bad aspects of what he has done. And that requires him to permit the good aspects of what he has done to offset the bad aspects of what he has done. In other words, for purposes of evaluating someone's blameworthiness the deontologist cannot help engaging in just exactly the kind of consequentalist calculation that he spurns when evaluating someone's decision.

It is time to return to the problem that got us into this little excursion, the question of how we should think about the person who manages to get to a forbidden end by a clever, seemingly moral means. Let's consider more closely the case of the man who joins the police force solely to get the opportunity one day to kill a criminal in self-defense. What makes the case so puzzling to people, and what I believe makes most cases of deft lawyerly planning so puzzling, is that they feel two contradictory impulses. The first impulse is that his decision to kill by joining the police force rather than by killing outright is not a spectacularly moral one. We may prefer that he do the former rather than the latter, but we don't think that it morally improves matters much. Yet we are prepared to judge the policeman who kills in the line of duty vastly differently from the person who does so outright. Those two impulses seem in conflict. How can one possibly make sense of them?

My distinction between the way a deontologist evaluates whether the defendant should or should not do something and the way he evaluates the moral position of an actor after he has acted allows us to make sense of those two impulses. Whether the defendant did or did not do the right thing need have no relationship to whether it improved his moral position. We saw that someone who does the wrong thing by killing the one for the sake of the many can nevertheless end up in a morally superior position to someone who does the right thing and refuses to kill the one for the sake of the many. A decision to do the wrong thing can improve one's moral position and vice versa. The strategizer is engaged in morally indifferent or morally bad decisions that spectacularly improve his moral position. That sounds strange, but is in the nature of deontology.

\section{CONCLUSION}

Lawyers routinely exploit law's formality. This Article explored the roots of this formality and the morality of the lawyer's exploitation thereof. Law is formalistic, I argue, because it mirrors an everyday morality that is formalistic. By the lights of that everyday morality, the lawyer's actions are often both morally effective and morally suspect. That paradoxical fact has to do with 
several things. First, lawyers frequently recommend client behavior that, although wrongful, subjects the other side to a moral constraint that disables it from acting, like stopping a tank by lying down in front of it. Second, lawyers frequently recommend client behavior that involves wrongful behavior that takes malicious advantage of a moral liberty, like hurting someone by reading a certain book. Third, and most importantly, lawyers frequently recommend client behavior that is wrong but that improves the client's moral position, like arranging to get a "free" killing by joining the police force and hoping for a self-defense opportunity. To be sure, not all lawyerly strategizing is like this. A lot of what people are most suspicious of-like turning euthanasia-by-act into euthanasia-by-omission-simply takes legitimate advantage of the path-dependent nature of moral rules. 